\title{
Chemical and Spectroscopic Parameters Are Equally Sensitive in Describing Soil Organic Matter Changes After Decades of Different Fertilization
}

\author{
Tomáš Šimon and Mikuláš Madaras * \\ Crop Research Institute, Drnovská 507, 16106 Prague, Czech Republic; simont@vurv.cz \\ * Correspondence: madaras@vurv.cz; Tel.: +420-702-087-690
}

Received: 31 August 2020; Accepted: 21 September 2020; Published: 22 September 2020

\begin{abstract}
The composition and dynamics of soil organic matter (SOM) are decisive factors in soil quality. In this work, total organic $\mathrm{C}\left(\mathrm{C}_{\text {tot }}\right)$, hot water extractable $\mathrm{C}\left(\mathrm{C}_{\mathrm{hwl}}\right)$, and aliphatic and aromatic SOM components detected by Fourier transform infrared (FTIR) spectroscopy were determined to evaluate SOM quantity and quality in soil samples taken between 2004 and 2017 from 13 field experiments established in different soil and climatic conditions of the Czech Republic. In addition, the $\mathrm{C}$ pool index (CPI), lability index (LI), C management index (CMI), and SOM decomposition index (DI) were assessed. Treatments were selected as follows: Unfertilized control (Nil), mineral fertilized treatment (NPK), farmyard manured treatment (FYM), and organic and mineral fertilized treatment (FYM+NPK). Both organic and combined fertilization significantly increased soil $\mathrm{C}_{\mathrm{tot}}, \mathrm{C}_{\mathrm{hwl}}, \mathrm{CPI}$, LI, CMI, and labile aliphatic SOM components (FTIR aliph) in most of the experiments compared to unfertilized treatments $(p \leq 0.05)$. In contrast, the highest content of recalcitrant aromatic SOM components $\left(\right.$ FTIR $_{\text {arom }}$ ) and increased DI were determined in majority of unfertilized soils. Our results show that: (1) fertilization regimes increased both labile and total $C$ pools; the highest increase was nearly uniformly observed for NPK+FYM treatment; (2) SOM chemical and FTIR spectral detection had equal sensitivity to the changes; and (3) none of the parameters or indices tested can be used as a stand-alone SOM quality descriptor.
\end{abstract}

Keywords: long-term experiments; fertilization; soil organic carbon; $\mathrm{C}$ fractions; organic matter indices

\section{Introduction}

Mineral and organic fertilizers have large effects on soil fertility. While organic amendments increase organic $\mathrm{C}$ and $\mathrm{N}$ content in the soils [1], mineral fertilizers increase $\mathrm{C}$ inputs indirectly through intensified growth of the fertilized crops and increased crop residues. On the other hand, mineral $\mathrm{N}$ fertilization promotes breakdown processes, and in the course of time, it can deplete soil organic C stocks [2].

Organic fertilization not only increases soil fertility but also influences its chemical, physical, and biological properties [3]. Content of organic matter in soil predominantly affects microbial biomass but also activity of various degrading enzymes [4]. It can affect the diversity and function of soil microorganisms, and thus also availability and recycling of nutrients, not only their actual content. Gu et al. [5] demonstrated that the combination of mineral fertilizers with farmyard manure increased the diversity of the soil bacterial community more than that of mineral fertilizers alone. Wei et al. [6] found that the structure and function of the bacterial community were similar in the manure-amended soil and the control treatment, suggesting that the application of manure increased microbial populations, but had little effect on bacterial community structure. Jangid et al. [3] ascribed the lower bacterial diversity in the inorganic fertilizer amended soils to decreased evenness. 
Long-term field experiments are useful in monitoring changes in $\mathrm{C}$ pools induced by cropping systems, soil management practices, and fertilizer usage [7]. In addition, the organic $\mathrm{C}$ content measured in topsoil samples taken from fertilized and unfertilized plots in long-term field experiments can be used to determine inert and decomposable $C$ content [8]. Although annual changes in total soil organic $C$ content did not exceed $0.01 \%$ [9], the labile $C$ fractions had a much shorter turnover time and proved more sensitive to changes in cultivation and agricultural management practices than the total organic $C$ content per se [10]. Hot water extractable $C$ provides information on the contents of the labile $\mathrm{C}$ pool which includes microbial biomass, soluble soil carbohydrates, and amines. It is considered a good indicator of soil quality [11], as it generally releases a much greater amount of labile organic $C$ that cold water and salt extractions. Further, it is possible to determine the status and rate of changes in soil organic carbon in agricultural systems using the $\mathrm{C}$ management index which includes both soil organic C pool and C lability [7,12].

Short- and long-term changes in soil organic matter (SOM) quality can be investigated using Fourier transform infrared (FTIR) spectroscopy and mid-infrared peak analyses [13]. FTIR assesses SOM transformations and stabilization by quantifying relative changes in aliphatic and aromatic functional groups which constitute the SOM [14]. Even small changes in SOM and its labile and stable components can be distinguished [15]. The ratio of recalcitrant/labile SOM components is significantly influenced by land management [16].

The aim of this study was to compare changes in soil $C$ fractions as a result of different fertilization in thirteen long-term field experiments. Another aim of the study was to compare detection sensitivity of chemical and spectroscopic methods to capture organic $C$ changes in the soil.

\section{Materials and Methods}

\subsection{Site Description and Experimental Design}

Long-term field experiments are located at different sites in the Czech Republic. Some were established 60 years ago and others later; mostly in the 1970s. The basic climatic and soil characteristics of the experimental sites are shown in Table 1. The oldest Czech field experiment is the Praha-Ruzyně fertilizer experiment (RFE) which contains five fields established according to the same design. Of these, fields B and IV were selected for this study, and they differ mainly in crop rotation. The crop rotation experiments (CRE) focused on plant nutrition and crop rotation were established with the same experimental design in Čáslav, Ivanovice, and Lukavec. The International Long-Term Organic Nitrogen Nutrition Experiments (IOSDV) were established at two sites (Ivanovice and Lukavec) and the Fraction Factorial Fertilization Experiment (FFFE) at five sites (Hněvčeves, Kostelec, Humpolec, Pernolec, Vysoké n.J.). Another trial is the Trutnov experiment, conducted at one site and focusing on straw application. Forage crops (alfalfa, red clover), cereals (winter wheat, spring barley), and root crops (sugar beet, potatoes) were mostly cultivated at these experimental sites, and conventional tillage (depth of plowing $25-28 \mathrm{~cm}$ ) was used in soil preparation.

The characteristics of individual experiments concerning crop rotations and doses of mineral and organic fertilizers are given in Table 2. Four basic treatments in each experiment were selected: Control treatments unfertilized from the commencement of the experiments (Nil), mineral fertilized treatments (NPK), farmyard manured treatments (FYM-25\% dry matter, $0.5 \% \mathrm{~N}$ content; $10 \mathrm{t} \mathrm{ha}^{-1} \mathrm{yea}^{-1}$ ) and organic and mineral fertilized treatments (FYM+NPK). Mineral fertilizer doses approximated local recommendations. No single NPK treatments were established in the CRE experiments. 
Table 1. Climatic and soil characteristics of the experimental sites.

\begin{tabular}{|c|c|c|c|c|c|c|c|c|}
\hline Site & ${ }^{\circ} \mathbf{N}$ & ${ }^{\circ} \mathbf{E}$ & Alt.(m) & $\mathrm{T}\left({ }^{\circ} \mathrm{C}\right)$ & Prec. (mm) & $\begin{array}{l}\text { Taxonomical } \\
\text { Units }\end{array}$ & $\begin{array}{l}\text { Texture } \\
\text { Class }\end{array}$ & $\begin{array}{c}\text { Clay Content } \\
(<0.002)(\%)\end{array}$ \\
\hline Ivanovice & 49.31 & 17.10 & 225 & 8.8 & 549 & $\begin{array}{l}\text { Luvi-haplic } \\
\text { Chernozem }\end{array}$ & Loam & 22 \\
\hline Čáslav & 49.89 & 15.39 & 240 & 8.9 & 555 & $\begin{array}{l}\text { Orthic } \\
\text { Greyzem }\end{array}$ & Loam & 21 \\
\hline Hněvčeves & 50.31 & 15.72 & 265 & 8.2 & 573 & Orthic Luvisol & Clay-loam & 20 \\
\hline Kostelec & 50.13 & 16.19 & 290 & 7.6 & 681 & Orthic Luvisol & Sandy-loam & 20 \\
\hline Praha-Ruzyně & 50.09 & 14.30 & 340 & 7.9 & 472 & Orthic Luvisol & Clay-loam & 33 \\
\hline Trutnov & 50.56 & 15.89 & 427 & 7.5 & 750 & $\begin{array}{l}\text { Euthric } \\
\text { Cambisol }\end{array}$ & Sandy-loam & 18 \\
\hline Humpolec & 49.56 & 15.35 & 525 & 6.5 & 667 & $\begin{array}{l}\text { Stagno-gleyic } \\
\text { Cambisol }\end{array}$ & Sandy-loam & 17 \\
\hline Pernolec & 49.78 & 12.68 & 530 & 7.1 & 559 & $\begin{array}{l}\text { Stagno-gleyic } \\
\text { Cambisol }\end{array}$ & Sandy-loam & 18 \\
\hline Lukavec & 49.56 & 14.98 & 610 & 6.8 & 667 & $\begin{array}{l}\text { Stagno-gleyic } \\
\text { Cambisol }\end{array}$ & Sandy-loam & 14 \\
\hline $\begin{array}{l}\text { Vysoké nad } \\
\text { Jizerou }\end{array}$ & 50.67 & 15.41 & 670 & 6.5 & 995 & $\begin{array}{l}\text { Dystric } \\
\text { Cambisol }\end{array}$ & Loamy-sand & 15 \\
\hline
\end{tabular}

Alt.—altitude, T—mean annual temperature, Prec.-mean annual precipitation sum.

Table 2. Crop rotations and fertilization in the long-term field experiments.

\begin{tabular}{|c|c|c|c|c|c|}
\hline \multirow{2}{*}{ Experiment } & \multirow{2}{*}{ Crop Rotation ${ }^{\text {a }}$} & $\mathbf{N}$ & $\mathbf{P}$ & $\mathbf{K}$ & \multirow{2}{*}{$\begin{array}{c}\text { Manure } \\
\text { t ha }^{-1} \text { year }^{-1}\end{array}$} \\
\hline & & \multicolumn{3}{|c|}{$\mathrm{kg} \mathrm{ha}^{-1}$ year $^{-1}$} & \\
\hline RFE field B & SW-SB & 100 & 26 & 75 & 10.5 \\
\hline RFE field IV & AL-AL-WW-SB-SBA-POT-WW-SB-SBA & 63 & 24 & 109 & 6.5 \\
\hline CRE & various-(WW or TR)-POT or CB or SM)-(SBA or WW) & 80 & 40 & 80 & 10 \\
\hline Trutnov exp. & WW-POT-SBA-LCM-WW-POT-O-CL & 71 & 33 & 99 & 10 \\
\hline FFFE & AL $\left(C^{b}\right)-W W-S M-W W-S B A-S B\left(\right.$ POT $\left.^{b}\right)-S B A$ & 100 & 40 & 70 & 10 \\
\hline IOSDV & $\mathrm{SB}\left(\mathrm{POT}^{\mathrm{c}}\right)-\mathrm{SBA}-\mathrm{WBA}$ & 120 & 35 & 83 & 10 \\
\hline
\end{tabular}

${ }^{a}$ AL-alfalfa (Medicago sativa L.), CL-red clover (Trifolium pratense L.), LCM-legume-cereal mixture, O—oat (Avena sativa L.), POT-potato (Solanum tuberosum L.), SB-sugar beet (Beta vulgaris subsp. vulgaris L.), SBA-spring barley (Hordeum vulgare conv. distichon (L.) Alef.), SM—maize for silage (Zea mays subsp. mays L.), SW—spring wheat (Triticum aestivum L.), TR-triticale (x Triticosecale Wittm. Ex A. Camus.), WBA-winter barley (Hordeum vulgare conv. vulgare L.), WW-winter wheat, (Triticum aestivum L.). ${ }^{\mathrm{b}}$ In Humpolec, Pernolec, and Vysoké n.J. ${ }^{\mathrm{c}}$ In Lukavec.

\subsection{Soil Sampling and Sample Processing}

Sampling of 0-0.2 m topsoil was performed in spring seasons from 2004 to 2017 at three sampling points in each plot. Partial soil samples were combined in 2-kg lots, homogenized, air-dried at room temperature and run through a 2-mm sieve. A total of 500 soil samples were collected. Total organic $\mathrm{C}\left(\mathrm{C}_{\text {tot }}\right)$ content was evaluated by Vario MAX CNS/CN analyzer (Elementar Analysensysteme $\mathrm{GmbH}$, Hanau, Germany). Hot water extractable $\mathrm{C}$ content $\left(\mathrm{C}_{\mathrm{hwl}}\right)$ was determined as in Körschens et al. [17]. The FTIR spectra were measured on the Thermo Nicolet Avatar 320 FTIR spectrometer (Nicolet, Madison, WI, USA) in a bulk soil and analyzed at absorption bands that indicate the aliphatic $\mathrm{C}-\mathrm{H}\left(3000-2800 \mathrm{~cm}^{-1}\right)\left(\mathrm{FTIR}_{\text {aliph }}\right)$ and aromatic $\mathrm{C}=\mathrm{C}\left(1660-1580 \mathrm{~cm}^{-1}\right)\left(\mathrm{FTIR}_{\text {arom }}\right)$ functional groups [13]. Decomposition index (DI) (intensity of FTIR spectra for $\mathrm{C}=\mathrm{C} / \mathrm{C}-\mathrm{H}$ functional groups) was calculated. $\mathrm{C}$ pool index (CPI), lability index (LI), and C management index (CMI) for each treatment were calculated as in Blair et al. [12]. In our study, Nil treatments were used as the reference for calculating CMI.

\subsection{Statistics}

The basic statistical values, i.e., averages, standard deviations, and Pearsons's correlation coefficients $(R)$, were calculated by Microsoft Excel (Microsoft Corporation, Redmund, WA, USA) and Statistica CZ 12.0 (StatSoft. Inc., Tulsa, OK, USA) software. Data for each year were analyzed by the 
analysis of variance, and Tukey's HSD test was used to determine significance of differences among individual treatments.

\section{Results and Discussion}

\subsection{Total Organic C}

Local site conditions as well as soil parameter heterogeneity caused large differences in $\mathrm{C}_{\text {tot }}$ in the unfertilized control treatments (Figure 1). The lowest $C_{\text {tot }}$ content of $0.97 \%$ was determined at Kostelec (Orthic Luvisol) and the highest of 1.96-1.97\% at Ivanovice (Luvi-haplic Chernozem) and Vysoké (Dystric Cambisol). The effect of mineral NPK fertilization on the $\mathrm{C}_{\text {tot }}$ content was positive in most sites; with an average increase of $0.9 \%$ compared to the unfertilized control. However, it was negative in Chernozem (Ivanovice IOSDV) and Dystric Cambisol (Vysoké n.J. FFFE); with an average $3.6 \%$ decrease. Mineral fertilizers accelerated decomposition and mineralization processes in these soils with the naturally highest $C_{\text {tot }}$ content. The observed $C_{\text {tot }}$ content decrease can be explained in terms of the priming effect, which is particularly strong in soils that are rich in C [18]. The increasing impact of FYM application on $C_{\text {tot }}$ was observed in experiments conducted in Hněvčeves, Kostelec, and Praha-Ruzyně, with an average increase of $10.5 \%$; and the $+4.8 \%$ additive effect of mineral NPK fertilizers to FYM determined a $15.3 \%$ average increase over Nil treatment. Increased $C_{\text {tot }}$ due to FYM and FYM+NPK application was statistically significant in most of experiments (excluding Pernolec and Vysoké n.J.). Likewise, Li et al. [19] indicated that the application of organic manure combined with inorganic fertilizer linearly increased soil organic $C$ levels.

\subsection{Hot Water Extractable $C$}

$\mathrm{C}_{\mathrm{hwl}}$ content ranged from 254 to $450 \mathrm{mgC} \mathrm{kg}^{-1}$ in unfertilized control treatments, and lower contents were determined in Luvisols (Hněvčeves, Kostelec, Praha-Ruzyně) and Euthric Cambisol (Trutnov). Conversely, the highest $\mathrm{C}_{\mathrm{hwl}}$ content was observed in sites at a higher altitude and lower average temperature (Cambisols in Lukavec and Vysoké). Significant responses of labile organic C to temperature changes were documented by Qi et al. [20]. The mineral and organic fertilizations mostly increased $\mathrm{C}_{\mathrm{hwl}}$ content, namely by an average of $5.4 \%$ in NPK, $15.9 \%$ in FYM, and 24.5\% in FYM+NPK treatments. This last increase in $\mathrm{C}_{\mathrm{hwl}}$ was statistically significant in nine of thirteen experiments, and the mean percentage increase in $\mathrm{C}_{\mathrm{hwl}}$ content in fertilized treatments was approximately 1.7 times greater than that for $\mathrm{C}_{\text {tot }}$ content in the unfertilized controls. Similarly, Schulz and Körschens [21] reported that hot water extractable carbohydrate and labile $C$ are more sensitive than $C_{\text {tot }}$ to different management practices, including fertilization. 

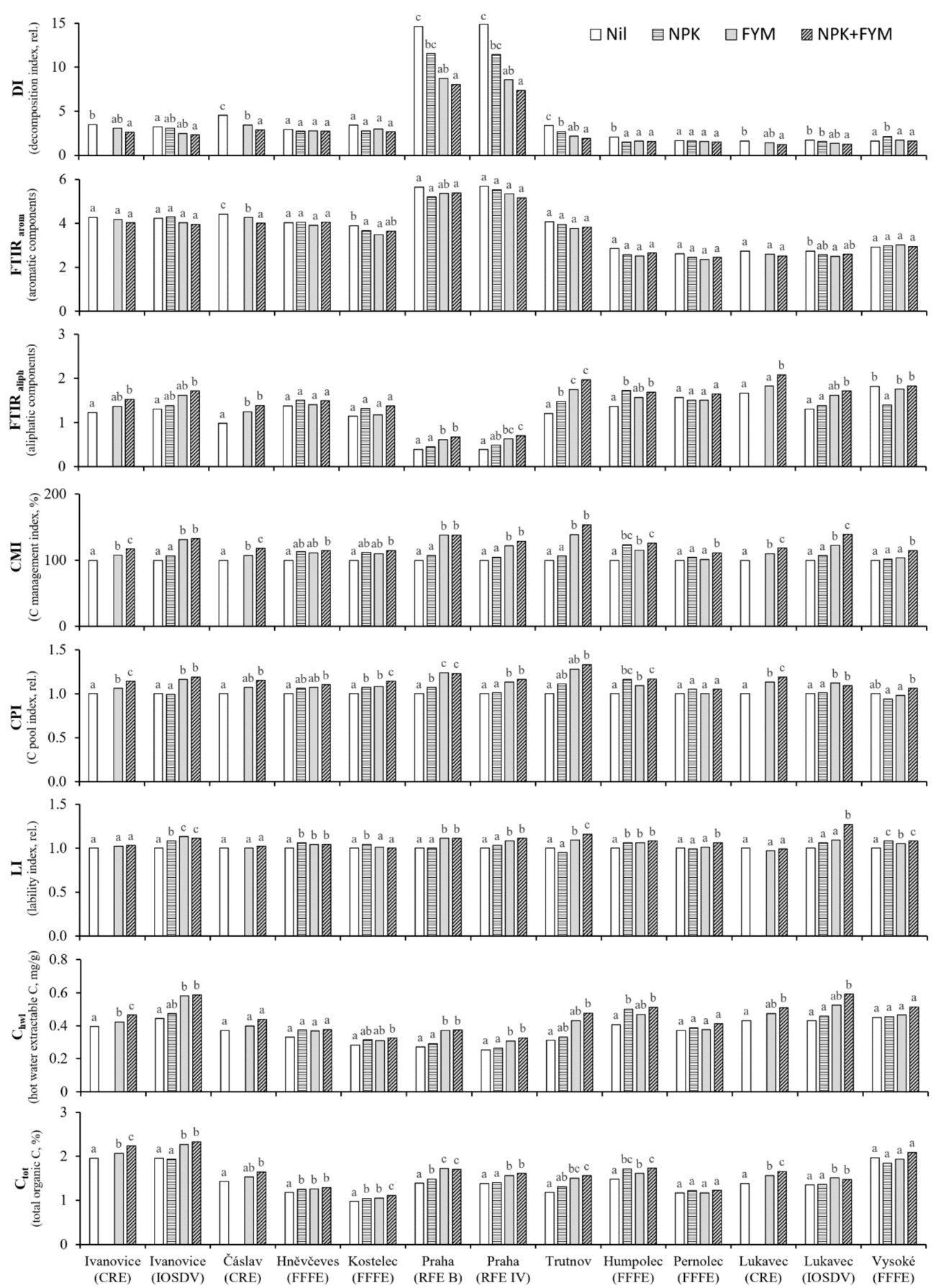

Figure 1. Soil organic carbon and derived indices characterizing soil samples; Nil—unfertilized treatments, NPK - mineral fertilized treatments, FYM—farmyard manured treatments, FYM+NPK— organic and mineral fertilized treatments, CRE—Crop Rotation Experiments, IOSDV—International Long-Term Organic Nitrogen Nutrition Experiments, FFFE-Fraction Factorial Fertilization Experiments, RFE B-Praha-Ruzyně Fertilizer Experiment field B, RFE IV—Praha-Ruzyně Fertilizer Experiment field 4. For a given combination of experiment and parameter, different letters indicate significant differences at $p \leq 0.05$.

\subsection{Indices Derived from Chemical Analyses}

Indices provide a sensitive measure of the rate of change in soil $C$ dynamics of a given system relative to a more stable reference soil [12]. Calculation was based on $C_{\text {tot }}$ and $C$ lability in the fertilized treatments and unfertilized controls; with CPI, LI, and CMI shown in Figure 1. The increase in the 
C pool index (CPI) and lability index (LI) calculated from all experiments averaged $5 \%$ CPI and $4 \%$ LI in NPK, $11 \%$ CPI and 5\% LI in FYM, and 16\% CPI and 8\% LI in FYM+NPK treatments. Increases of CPI and LI from organic fertilization were statistically significant in the majority of cases. Mineral and especially organic fertilization led to increases in $C_{h w l}$ as a percentage of $C_{\text {tot }}$ and consequently increased CMI compared with control treatments. On average, NPK increased CMI by 8.5\%, FYM by $16.8 \%$, and FYM+NPK by $25.2 \%$. Increased CMI from organic and mineral fertilization was statistically significant in all experiments. These results indicate a shift in $\mathrm{C}$ dynamics by organic material addition compared to those in unfertilized and mineral fertilized soils [7].

\subsection{FTIR Spectroscopy-Aliphatic and Aromatic SOM Components}

A wide range of values was recorded for FTIR aliph (from 0.382 in Praha-Ruzyně to 1.810 in Vysoké) and also for FTIR arom (from 2.619 to 5.687; Figure 1). Mineral and organic fertilizations influenced SOM composition in soil; while aliphatic SOM components increased due to fertilization (on average by $4.4 \%$ in NPK, $14.8 \%$ in FYM, and 25.9\% in FYM+NPK treatment). Aromatic components in fertilized treatments decreased an average of 3.3-5.8\% compared to unfertilized treatments. These results correspond with the findings of Demyan et al. [13], who described a significantly higher relative peak area of FTIR spectra specific for aliphatic SOM components than for aromatics in farmyard manured plots compared with unfertilized plots in Haplic Chernozem.

\subsection{Index Derived from FTIR Spectra}

The index of relative decomposition and recalcitrance of SOM (DI), hypothesized by Margenot et al. [22] as a measure unit of organic matter transformation in soil, is shown in Figure 1. Substantially lower DI in FYM and FYM+NPK treatments than in unfertilized treatments, on average by $29-36 \%$, suggests differences in the degree of decomposition and transformation of soil organic matter depending on different fertilization regimes. Repeated application of farmyard manure supplies the soil with a greater amount of organic matter which is gradually and slowly transformed into more stable components. In contrast, rapid SOM decomposition is especially characteristic of soils lacking adequate organic matter input. Therefore, DI increases with an increasing degree of decomposition and lower degree of decomposition is positively associated with soil organic carbon increases [16].

\subsection{Relationships}

Correlation coefficients $(R)$ for the evaluated soil characteristics are shown in Table 3 . $C_{\text {tot }}$ correlated significantly only with $\mathrm{C}_{\mathrm{hwl}}, \mathrm{LI}$, and CMI, while $\mathrm{C}_{\mathrm{hwl}}$ significantly positively correlated with FTIR $\mathrm{R}_{\text {aliph }}$ and negatively with FTIR arom SOM components. These correlations indicate the labile nature of SOM fractions extracted by hot water. Negative correlations between FTIR arom SOM components and $C_{h w l}$ refer to the recalcitrant character of aromatic components which form the stable portion of SOM. The CPI, LI, and CMI indices positively correlated with $\mathrm{C}_{\mathrm{hwl}}$ which indicates the importance of the labile $\mathrm{C}$ fraction in soil $\mathrm{C}$ dynamics and soil quality.

Table 3. Relationships between characterized soil parameters (correlation coefficients $R$ ).

\begin{tabular}{cccccccc}
\hline Parameter & C tot $_{\text {to }}$ & Chwl $_{\text {hw }}$ & FTIR $_{\text {aliph }}$ & FTIR $_{\text {arom }}$ & DI & CPI & LI \\
\hline C $_{\text {hwl }}$ & $0.636^{* *}$ & & & & & & \\
FTIR $_{\text {aliph }}$ & 0.205 & $0.741^{* *}$ & & & & & \\
FTIR $_{\text {arom }}$ & 0.080 & $-0.576^{* *}$ & $-0.818^{* *}$ & & & & \\
DI & -0.074 & $-0.634^{* *}$ & $-0.906^{* *}$ & $0.840^{* *}$ & & & \\
CPI & 0.215 & $0.296^{*}$ & 0.178 & 0.118 & -0.044 & & \\
LI & $0.312^{*}$ & $0.515^{* *}$ & 0.130 & 0.003 & -0.073 & $0.466^{* *}$ & \\
CMI & $0.292^{*}$ & $0.439^{* *}$ & 0.177 & 0.091 & -0.057 & $0.909^{* *}$ & $0.791^{* *}$ \\
\hline
\end{tabular}

Statistically significant at the level of significance: ${ }^{*} p \leq 0.05 ;{ }^{* *} p \leq 0.01$. 
Significant opposite effects of altitude, average temperature, and precipitation have been documented for FTIR aliph and FTIR arom SOM components (data not shown). These results highlight that more clayey soils from lower altitudes with higher average temperatures and lower precipitation contain more aromatic SOM components and have a higher DI. Conversely, sandy soils from higher altitudes with a lower average temperature and higher rainfall contain more labile $\mathrm{C}$ components. Lower temperatures at higher altitudes limit $C$ turnover, and this results in increased $C$ accumulation even under conditions of less productivity and $C$ input [23]. Our results show that temperature and precipitation play a major role in regulating decomposition of different soil organic matter fractions in various site conditions.

\subsection{Detection of Soil Organic Carbon Changes}

The relative sensitivity of soil organic matter parameters and indices to fertilization-induced changes is compared in Figure 2. Results show that the response to fertilization regimes of both direct chemical analysis and indirect FTIR spectroscopic detection is comparable in its extent. For the NPK+FYM treatment, the CMI index derived from chemical analysis increases an average of $25 \%$ compared to the Nil treatment reference, while the DI derived from FTIR spectra decreased by $36 \%$. The CMI index proved less variable and more robust because its increase is statistically significant for all 13 experiments, while the DI change was not significant in 4 experiments. Therefore, while FTIR spectra and derived indices can be used for fast and less expensive indications of soil properties, quality changes, and mapping [24], the more laborious chemical analyses appear slightly more robust at detecting soil organic $\mathrm{C}$ changes. A combination of both approaches, after careful calibration of the spectroscopic method for different soil types and geographic areas, can reduce the need for combustion-based soil analysis and will provide faster and cheaper information on SOM status and trends [25].

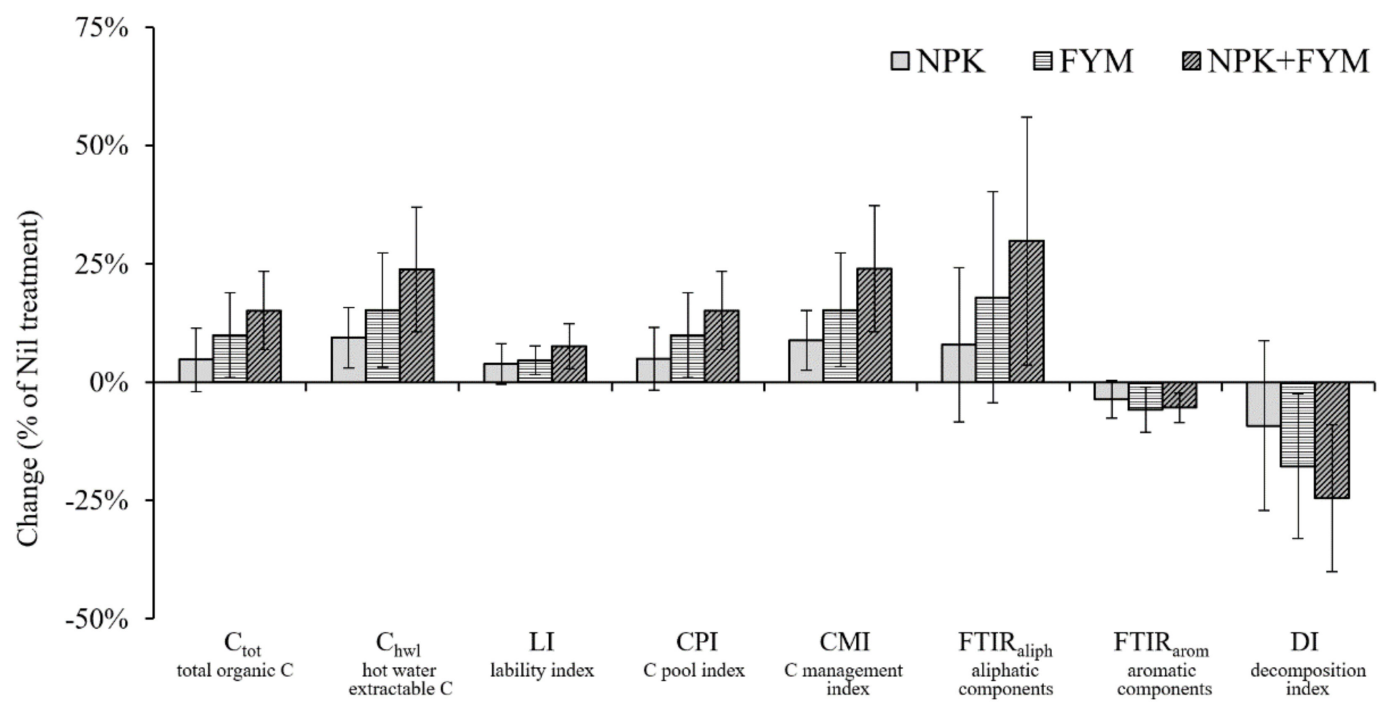

Figure 2. Change of soil organic matter parameters and indices related to unfertilized control treatment (averages of all experiments). Bars signify the standard deviation.

\section{Conclusions}

This study summarizes the effects of different fertilization input on soil organic $C$ fractions in thirteen long-term field experiments. Fertilization regimes produce in the long-term a larger amount of both labile and total $C$ pools and transformation processes are slow and incomplete due to repeated organic matter input. Without regular manure fertilization under intensive farming, higher soil C sequestration cannot be ensured. That must be taken into account in the case of farms without livestock. We can consider at particular sites (under long-term farming practice including balanced crop rotation 
and regular farmyard manure application) that soil organic $C$ is in an optimal state after decades, which signals good farming practice. The optimal SOM state can be evidenced by stable soil C levels in organically fertilized treatments during the monitored years.

An important conclusion arising from our results is that none of the investigated parameters or indices can be used as absolute indicators of whether the state of soil organic $C$ is satisfactory or not. However, the direction of soil organic matter changes can be deduced only from comparison with reference plots, or from time-trend analysis supported by knowledge of fertilizer and manure inputs.

Author Contributions: Data curation T.Š. Funding acquisition M.M. Investigation T.Š. Methodology M.M. Project administration M.M. Visualization M.M. Writing—original draft T.Š. Writing-review and editing M.M. All authors have read and agreed to the published version of the manuscript.

Funding: This research was funded by Ministry of Agriculture of the Czech Republic, project no. QK1810186 and institutional support MZE-RO0418.

Conflicts of Interest: The authors declare no conflict of interest.

\section{References}

1. Maillard, E.; Angers, D.A. Animal manure application and soil organic carbon stocks: A meta-analysis. Glob. Chang. Biol. 2013, 20, 666-679. [CrossRef] [PubMed]

2. Moeskops, B.; Buchan, D.; Van Beneden, S.; Fievez, V.; Sleutel, S.; Gasper, M.S.; D’Hose, T.; De Neve, S. The impact of exogenous organic matter on SOM contents and microbial soil quality. Pedobiologia 2012, 55, 175-184. [CrossRef]

3. Jangid, K.; Williams, M.A.; Franzluebbers, A.J.; Sanderlin, J.S.; Reeves, J.H.; Jenkins, M.B.; Endale, D.M.; Coleman, D.S.; Whitman, W.B. Relative impacts of land-use, management intensity and fertilization upon soil microbial community structure in agricultural systems. Soil Biol. Biochem. 2008, 40, 2843-2853. [CrossRef]

4. Mikanová, O.; Šimon, T.; Kopecký, J.; Ságová-Marečková, M. Soil biological characteristics and microbial community structure in a field experiment. Open Life Sci. 2015, 10, 249-259. [CrossRef]

5. Gu, Y.; Zhang, X.; Tum, S.; Lindstrom, K. Soil microbial biomass, crop yields, and bacterial community structure as affected by long-term fertilizer treatments under wheat-rice cropping. Eur. J. Soil. Biol. 2009, 45, 239-246. [CrossRef]

6. Wei, D.; Yang, Q.; Zhang, J.Z.; Wang, S.; Chen, X.L.; Zhang, X.L.; Li, W.Q. Bacterial community structure and diversity in a black soil as affected by long-term fertilization. Pedeosphere 2008, 18, 582-592. [CrossRef]

7. Yang, X.; Ren, W.; Sun, B.; Zhang, S. Effects of contrasting soil management regimes on total and labile soil organic carbon fractions in a loess soil in China. Geoderma 2012, 177-178, 49-56. [CrossRef]

8. Körschens, M. Importance of soil organic matter (SOM) for biomass production and environment (a review). Arch. Agron. Soil Sci. 2002, 48, 89-94. [CrossRef]

9. Körschens, M.; Kubát, J. Soil organic matter-Climate change-Carbon sequestration? The importance of long-term field experiments. In 60th Anniversary of Long-Term Field Experiments in the Czech Republic. Book of Abstracts and Proceedings of the International Conference; Crop Research Institute: Prague, Czech Republic, 2015; pp. 43-50.

10. Haynes, R.J. Labile organic matter fractions as central components of the quality of agricultural soils: An overview. Adv. Agron. 2005, 85, 221-268.

11. Ghani, A.; Dexter, M.; Perrot, K.W. Hot-water extractable carbon in soils: A sensitive measurement for determining impacts of fertilization, grazing and cultivation. Soil Biol. Biochem. 2003, 35, 1231-1243. [CrossRef]

12. Blair, G.J.; Lefroy, R.D.B.; Lisle, L. Soil carbon fractions based on their degree of oxidation and the development of a carbon management index for agricultural systems. Aust. J. Agric. Res. 1995, 46, 1459-1466. [CrossRef]

13. Demyan, M.S.; Rasche, F.; Schulz, E.; Breulmann, M.; Müller, T.; Cadisch, G. Use of specific peaks obtained by diffuse reflectance Fourier transform mid-infrared spectroscopy to study the composition of organic matter in a Haplic Chernozem. Eur. J. Soil Sci. 2012, 63, 189-199. [CrossRef]

14. Chefetz, B.; Hader, Y.; Chen, Y. Dissolved organic carbon fractions formed during composting of municipal solid waste: Properties and significance. Acta Hydrochim. Hydrobiol. 1998, 26, 172-179. [CrossRef] 
15. Calderón, F.; Haddix, M.; Conant, R.; Magrini-Bair, K.; Paul, E. Diffuse-Reflectance Fourier Transform Mid-Infrared Spectroscopy as a method of characterizing changes in soil organic matter. Soil Sci. Soc. Am. J. 2013, 77, 1591-1600. [CrossRef]

16. Stehlíková, I.; Madaras, M.; Lipavský, J.; Šimon, T. Study on some soil quality changes obtained from long-term experiments. Plant Soil Environ. 2016, 62, 74-79. [CrossRef]

17. Körschens, M.; Schulz, E.; Behm, R. Hot water extractable carbon and nitrogen of soils as a criterion for their ability of N-release. Zbl. Mikrobiol. 1990, 145, 305-311.

18. Kuzyakov, Y.; Friedel, J.K.; Stahr, K. Review of mechanisms and quantification of priming effects. Soil Biol. Biochem. 2000, 32, 1485-1498. [CrossRef]

19. Li, Z.P.; Liu, M.; Wu, X.C.; Han, F.X.; Zhang, T.L. Effects of long-term chemical fertilization and organic amendments on dynamics of soil organic $\mathrm{C}$ and total $\mathrm{N}$ in paddy soil derived from barren land in subtropical China. Soil Till. Res. 2010, 106, 268-274. [CrossRef]

20. Qi, R.; Li, J.; Lin, Z.; Li, Z.; Li, Y.; Yang, X.; Zhang, J.; Zhao, B. Temperature effects on soil organic carbon, soil labile organic carbon fractions, and soil enzyme activities under long-term fertilization regimes. Appl. Soil Ecol. 2016, 102, 36-45. [CrossRef]

21. Schulz, E.; Körschens, M. Characterization of the decomposable part of soil organic matter (SOM) and transformation processes by hot water extraction. Eurasian Soil Sci. 1998, 31, 809-813.

22. Margenot, A.J.; Calderón, F.J.; Bowles, T.M.; Parikh, S.J.; Jackson, L.E. Soil organic matter functional group composition in relation to organic carbon, nitrogen, and phosphorus fractions in organically managed tomato fields. Soil Sci. Soc. Am. J. 2015, 79, 772-782. [CrossRef]

23. Leifeld, J.; Bassin, S.; Fuhrer, J. Carbon stocks in Swiss agricultural soils predicted by land-use, soil characteristics, and altitude. Agric. Ecosyst. Environ. 2005, 105, 255-266. [CrossRef]

24. Rial, M.; Cortizas, A.M.; Rodríguez-Lado, L. Mapping soil organic carbon content using spectroscopic and environmental data: A case study in acidic soils from NW Spain. Sci. Total Environ. 2016, 539, $26-35$. [CrossRef] [PubMed]

25. Paustian, K.; Collier, S.; Baldock, J.; Burgess, R.; Creque, J.; DeLonge, M.; Dungait, J.; Ellert, B.; Frank, S.; Goddard, T.; et al. Quantifying carbon for agricultural soil management: From the current status toward a global soil information system. Carbon Manag. 2019, 10, 567-587. [CrossRef] 